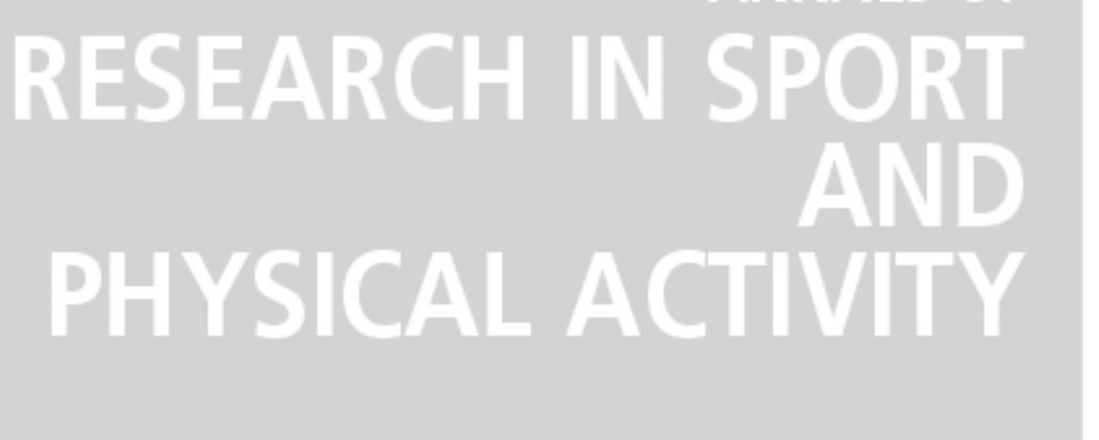

Effect of exam periods on physical activity and the immune-neuroendocrine response in university students

Autor(es): $\quad$ Hinchado, MD; Gálvez, I; Martín-Cordero, L; Marín, J; Ortega, E

Publicado por: Imprensa da Universidade de Coimbra

URL persistente:

URI:http://hdl.handle.net/10316.2/44161

DOI:

DOI:https://doi.org/10.14195/2182-7087_ex2018_99

Accessed : $\quad$ 26-Apr-2023 10:18:46

A navegação consulta e descarregamento dos títulos inseridos nas Bibliotecas Digitais UC Digitalis, UC Pombalina e UC Impactum, pressupõem a aceitação plena e sem reservas dos Termos e Condições de Uso destas Bibliotecas Digitais, disponíveis em https://digitalis.uc.pt/pt-pt/termos.

Conforme exposto nos referidos Termos e Condições de Uso, o descarregamento de títulos de acesso restrito requer uma licença válida de autorização devendo o utilizador aceder ao(s) documento(s) a partir de um endereço de IP da instituição detentora da supramencionada licença.

Ao utilizador é apenas permitido o descarregamento para uso pessoal, pelo que o emprego do(s) título(s) descarregado(s) para outro fim, designadamente comercial, carece de autorização do respetivo autor ou editor da obra.

$\mathrm{Na}$ medida em que todas as obras da UC Digitalis se encontram protegidas pelo Código do Direito de Autor e Direitos Conexos e demais legislação aplicável, toda a cópia, parcial ou total, deste documento, nos casos em que é legalmente admitida, deverá conter ou fazer-se acompanhar por este aviso. 


\section{ANNALS OF RESEARCH IN SPORT AND PHYSICAL ACTIVITY}




\title{
EFFECT OF EXAM PERIODS ON PHYSICAL ACTIVITY AND THE IMMUNE-NEUROENDOCRINE RESPONSE IN UNIVERSITY STUDENTS
}

\author{
Hinchado MD; Gálvez I'; Martín-Cordero L²; Marín J3; Ortega E¹
}

KEYWORDS: Phagocytic process, neutrophils, stress, cortisol, sedentary lifestyle

Living a healthy lifestyle is crucial in order to prevent numerous diseases. Lifestyle is affected by several factors such as eating habits, toxic habits, physical activity, sleep patterns and psychological factors. In particular, physical activity is a major health determinant. Nowadays, sedentary lifestyle and physical inactivity are considered a worldwide health problem $^{(1)}$. The purpose of this study was to analyze how exam periods may affect physical activity and immune-neuroendocrine parameters in young university students. A group of 8 healthy students from 19 to 26 years in age were enrolled in the study. Anthropometric measurements (weight, body mass index and waist-hip ratio) were taken using standardized methods. Daily physical activity and the Metabolic Equivalent of Task (MET) were measured using accelerometers (ActiGraph wGT3X-BT) for 4 days. Fasting plasma glucose levels were determined using blood glucose strips, and cortisol serum levels were measured by ELISA. The phagocytic process was evaluated in neutrophils from peripheral blood. Chemotaxis was evaluated in isolated neutrophils using a Boyden chamber, and the phagocytic and microbicide capacities were evaluated in whole blood by flow cytometry. Evaluation of all of these parameters was carried out both in the exam period and in the post-exam period. During the exam period, the students presented a higher weight and body mass index. They performed less and shorter bouts of activity, less minutes of moderate-to-vigorous intensity physical activity and fewer steps than after exams. Students during exams also showed lower MET values, decreased glucose levels, and higher cortisol levels. During the exam period, students presented a reduced chemotaxis index, and decreased phagocytic

\footnotetext{
1 Immunophysiology Research Group, Department of Physiology, University of Extremadura, Spain.

2 Immunophysiology Research Group, Department of Nursing, University of Extremadura, Spain;

${ }^{3}$ Department of Analytical Chemistry, Faculty of Sciences, University of Extremadura, Spain.

Email: orincon@unex.es; leticiamartin@unex.es; igalvez@unex.es
} 
and microbicide capacities of neutrophils; which may suggest a suppression of the immune system's defenses against pathogens. Taken as a whole, these results clearly suggest that the exam period deeply affected lifestyle since it had a significant impact on different aspects of the students' health such as physical activity, anthropometric measurements, and immune and endocrine parameters. Nevertheless, despite the improvement in physical activity in the post-exam period in relation to the exam period, both situations reflect worrying high levels of physical inactivity that may contribute to the onset of sedentary lifestyle-related pathologies in the future.

This investigation has been supported by Junta de Extremadura-FEDER (GR-15041). We would like to thank the volunteers and the STAB (UEx) for technical and human support.

\section{REFERENCES}

1. Blair, S.N. (2009). Physical inactivity: the biggest public health problem of the 21st century. British Journal of Sports Medicine. 43 $3^{(1)}: 1-2$. 